\title{
The Synchronization Necessary of Notary Supervision by Notary Supervisory and Honour Council
}

\author{
Suwardi*) \\ *) Faculty of Law, Universitas Islam Sultan Agung (UNISSULA) Semarang, E-mail: \\ suwardi123@gmail.com
}

\begin{abstract}
In line with the Notary's accountability for his authority, and compliance with that authority, legal certainty must be guaranteed with a continuous and effective supervision and guidance. There are currently two notary supervision and guidance institutions in Indonesia, namely the Notary Supervisory Council and the Notary Honorary Council. This study uses a normative juridical approach, which is a research that is focused on examining the application of norms or norms in positive law. Article 67 paragraph (2) of Act No. 2 of 2014 states that the Notary Supervisory Council shall supervise notaries including the behavior of the notary and the implementation of office by the notary. Meanwhile, the Honorary Council itself only provides guidance and supervision to the extent that it violates ethics. What must be remembered is that the authority possessed by the Notary Supervisory Council looks so 'broad'. This is because the Notary Supervisory Council is not only authorized to carry out guidance and supervision of notaries who violate the provisions of the law. However, the Notary Supervisory Council also provides guidance and supervision of ethical violations as carried out by the Honorary Council. The conclution of this reseach is Synchronization of Notary Supervision by the Notary Supervisory Council and guidance by the Notary Honorary Council in law enforcement is very necessary.
\end{abstract}

Keywords: Authority; Supervision; Guidance; Notary; Council.

\section{INTRODUCTION}

The Notary Institution, one of the social institutions in Indonesia, arises from the need in human relations that requires a means of evidence regarding the civil law relationship that exists and or occurs between them. The authority of a notary is regulated in Article 1 number 1 of Act No. 2 of 2014 concerning Amendments to Act No. 30 of 2004 concerning the Position of a Notary (hereinafter abbreviated as UUJN) which states that: "Notary is a public official who is authorized to make authentic deeds and has other powers as referred to in this Law or based on other laws."

Supervision is any effort or activity to find out and assess the actual reality of the implementation of a task or activity, whether it is in accordance with it or not. Supervision is the process of observing the implementation of all organizational activities to ensure 
that all work being carried out goes according to a predetermined plan. ${ }^{1}$ Supervision is also one of the basic functions of management which in English is called controlling. In Indonesian, there are two functions of controlling, namely supervision and control. ${ }^{2}$

Notary Supervisory Council established by the Minister of Law and Human Rights, as the only agency authorized to supervise, examine and impose sanctions on Notaries. The Notary Supervisory Council consists of three levels, where each level has its own authority starting from the Regional Supervisory Council (MPD), the Regional Supervisory Council (MPW) and the Central Supervisory Council (MPP).

Article 66 of Act No. 30 Year 2004 concerning Notary Position states that the Notary Supervisory Council has the authority to approve or reject the matter of taking photocopies of the minimum deed and summoning a Notary for the benefit of the judicial process, investigators, public prosecutors, or judges. After the decision of the Constitutional Court Number 49/PUU-X/2012, the authority of the Regional Supervisory Council regarding the withdrawal of deeds and summons of Notaries, resulted in an amendment to Act No. 30 of 2004 which was amended by Act No. 2 of 2014 concerning the Position of Notary Public. The authority is then transferred to the Notary Honorary Council.

Based on Article 66 UUJN, for the purposes of judicial process, investigators, public prosecutors, or judges with the approval of the Notary Honorary Council (MKN) are authorized to: (21) Take photocopies of Minuta Deeds and/or letters attached to Minuta Deeds or Notary Protocols in storage Notary Public; and (2) summon the Notary Public to be present in the examination relating to the Notary Deed or Protocol that is in the Notary's custody. Articles 66A and 67 of the UUJN clearly show the differences between the two assemblies. The Notary Honorary Council (MKN) has the authority to carry out "coaching", the Notary Supervisory Council (MPN) has the authority to carry out "supervision". Fostering and supervision of Notaries are essentially towards order and legal certainty in the framework of the Notary's responsibilities for positions and authorities in accordance with statutory orders.

Maintaining law order and legal certainty in society is known as law enforcement. Therefore, in order to regulate the functions, duties and authorities of the institutions in charge of enforcing the law according to the proportion of their respective scopes, and based on a good system of cooperation and supporting the goals to be achieved. Law enforcement can also be defined as the administration of law by law enforcement officers and by everyone who has an interest in accordance with their respective authority according to the applicable legal rules. Enforcement of the criminal law is an integrated process that begins with the investigation, arrest, detention, trial of the accused and ends with the convict's correctional facility. ${ }^{3}$ According to Soerjono Soekanto, law enforcement is an activity to harmonize the relationship of values that are described in moral principles and attitudes as a series of defining the final stage of values. To create, maintain and maintain a peaceful relationship in life ${ }^{4}$. Law enforcement in this field is very important,

\footnotetext{
${ }^{1}$ Sujamto. (1987). Aspek-aspek Pengawasan di Indonesia. Jakarta: Sinar Grakika, p. 53.

${ }^{2}$ Ngadino. (2019). Duties and Responsibilities, Position of Notary in Indonesia. PGRI University, Semarang Press, p. 65.

${ }^{3}$ Harun M. Husen. (1990). Penegakan Hukum di Indonesia. Rineka Cipta, Jakarta, p. 58.

${ }^{4}$ Soerjono Soekanto, (183). Faktor Keefektifan Penegakan Hukum. UI Pres, Jakarta, p. 35.
} 
because notary is a legal profession so that the notary profession is a noble profession (nobile officium). Notaries are called noble officials because the notary profession is closely related to humanity.

Barda Nawawi Arief, mentioned the formulation stage, namely the stage of criminal law enforcement in abstract by the legislative body. In this stage, legislators carry out activities to select values that are in accordance with the current and future circumstances and situation, then formulate them in the form of criminal legislation to achieve the best statutory results in the sense of fulfilling the requirements of justice (legal certainty and usefulness) as well as usability. This stage is called the Legislative Policy Stage. ${ }^{5}$

Legal synchronization is the harmonization and harmonization of various laws and regulations related to existing and currently drafting laws that govern a particular field. The purpose of synchronization activities is so that the substances regulated in legislation products do not overlap, complement each other (supplementary), are interrelated, and the lower the type of regulation, the more detailed and operational the content will be. The purpose of synchronization activities is to create a regulatory foundation for a particular field that can provide adequate legal certainty for the efficient and effective administration of certain fields. ${ }^{6}$

Based on the description above, there are things that must be avoided in the implementation phase of the law, there will be overlaps and confusion about the supervisory authority by the Notary Supervisory Council and the guidance authority by the Notary Honorary Council in the framework of law enforcement, due to the formulation stage of the legislation, there is no harmony, differences and contradictions which ultimately constitute an inhibiting factor in law enforcement. Therefore, legal synchronization is very important because the purpose of synchronization activities is to realize the basis for the regulation of a certain field, namely related to notary institutions, which can provide adequate legal certainty for the efficient and effective administration of that field?.

Based on the background of the problem as described above, the problem discussed in the research is "how is the synchronization of Notary supervision by the Notary Supervisory Council and guidance by the Notary Honorary Council in law enforcement".

The research objective is to find out and analyze the synchronization of the formulation of Notary supervision arrangements by the Notary Supervisory Council and the guidance of Notaries by the Notary Honorary Council in law enforcement.

This thesis research is also expected to be useful and beneficial both theoretically and practically. Theoretically, this research is expected to add scientific insight to the science of

${ }^{5}$ Barda Nawawi Arief. (2002). Kepentingan dalam Kebijakan Hukum Pidana. Bandung: PT Citra Aditya Bakti, p. 12.

${ }^{6}$ Suhartono. (2011). Harmonization of Legislative Regulations in the Implementation of the State Budget (Efficient, Effective and Accountable Solution for State Budget Absorption), Thesis, Jakarta: University of Indonesia, p. 94.

${ }^{7}$ S Bahri, A Yahanan, A Trisaka. (2009). Kewenangan Notaris Dalam Mensertifikasi Transaksi

Elektronik dalam rangka Cyber Notary, Repertorium: Jurnal Ilmiah Hukum Kenotariatan, p. 142157 
notary law, especially notary supervision by the Notary Supervisory Council and Notary guidance by the Notary Honorary Council in law enforcement. Practically the results of this research are expected to be material for consideration and contribution of thought, and can provide concrete contributions and solutions for legal practitioners in terms of Notary supervision by the Notary Supervisory Council and Notary guidance by the Notary Honorary Council in law enforcement.

\section{RESEARCH METHODS}

This study uses a normative juridical approach, which is a research that is focused on examining the application of norms or noms in positive law. The object of this research is positive law regarding synchronization of supervision and guidance for Notaries by the Notary Supervisory Council and Notary Honorary Council in law enforcement. Judging from its nature, this research is a qualitative descriptive study, namely research that is intended to provide data as accurate as possible about humans or other conditions and symptoms. ${ }^{8}$ With the data source, literature study is derived from secondary data, so that in accordance with the normative juridical approach method, the library material is the basic data which in the study is classified as secondary data. Secondary data collected in this study consisted of: primary legal materials, namely binding legal materials related to inheritance law, including secondary legal materials, namely materials that provided an explanation of primary legal materials, including: writings or opinions of legal experts. , law joumals, research results and tertiary legal materials consist of: Legal Dictionary, Enhanced Spelling, Encyclopedia.

In addition to secondary data, it also uses primary data which is obtained directly from the source through interviews. Interview using interview guidelines. At first, the respondents were asked structured questions, then some points from the questions were deepened to obtain further information. Thus, it is hoped that a complete and in-depth answer will be obtained. The collected data is then analyzed, namely a process of systematic and consistent breakdown of certain symptoms. Legal research materials in the form of secondary data and primary data collected are then analyzed qualitatively, namely describing and interpreting an object according to the fact that is related to synchronization of supervision and guidance of Notaries by the Notary Supervisory Council and Notary Honorary Council in law enforcement. ${ }^{9}$

\section{RESULTS AND DISCUSSION}

In principle, the supervision and guidance carried out by the Honorary Council and the Notary Supervisory Council are not much different, namely to protect the dignity of Notaries as public officials in carrying out their duties and functions. The limitation of the coaching carried out by the Honorary Council and the Supervisory Council is in terms of the time or time the coaching is carried out. The Notary Honorary Council provides guidance when a notary is dealing with legal issues, where the Regional Honorary Council checks applications submitted by investigators, public prosecutors, and judges in order to then give or not give permission/approval to the request for notary summons to be

\footnotetext{
${ }^{8}$ Soeryono Soekanto. (1986). Pengantar Ilmu Hukum. UI Press, Jakarta, p. 10.

${ }^{9}$ NI Puspita. (2019). Persetujuan Majelis Kehormatan Notaris Untuk Pengambilan Fotokopi Minuta Akta Dan Pemanggilan Notaris Dalam Rangka Proses Peradilan. Repertorium: Jurnal Ilmiah Hukum Kenotariatan 4, p.2
} 
present in the trial process. Meanwhile, the Notary Supervisory Council provides guidance on a day-to-day basis or every moment related with the duties, obligations, prohibitions or exceptions of a notary in carrying out his/her position so that a notary is not caught in legal issues for violations of the Notary Position Law and the Notary's Code of Ethics.

There are several confusion and imbalances in the supervision and guidance of Notaries by the Honorary Council and the Notary Supervisory Council, including:

(1) There is an imbalance of authority between the Notary Supervisory Council and the Notary Honorary Council.

Article 67 paragraph (2) of Act No. 2 of 2014 states that the Notary Supervisory Council shall supervise notaries including the behavior of the notary and the implementation of office by the notary. Meanwhile, the Honorary Council itself only provides guidance and supervision to the extent that it violates ethics. What must be remembered is that the authority possessed by the Notary Supervisory Council looks so 'broad'. This is because the Notary Supervisory Council is not only authorized to carry out guidance and supervision of notaries who violate the provisions of the law. However, the Notary Supervisory Council also provides guidance and supervision of ethical violations as carried out by the Honorary Council. The Honorary Council is an internal organization, it only provides guidance and supervision for ethical violations. Ethics in the Code of Ethics of the Indonesian Notary Association (INI), he's just that. He was not in violation of the law.

In terms of the sanctions that are stipulated, it has different implications for the notary profession itself. For example, the Honorary Council may impose the most severe sanctions in the form of honorific dismissal or disrespect for notaries as limited as their status as members of professional organizations. On the other hand, the Notary Supervisory Council can impose the heaviest sanctions, for example the dismissal of a Notary from his profession or position.

Honorary Council sanctions are related to organizational sanctions not sanctions against office. For example, dismissal as a member of the Indonesian Notary Association (INI). Notary is still a notary profession because the Honorary Council has no right to do that. If in the Notary Supervisory Council, he can propose dismissal or dismissal as a notary, that is the heaviest sanction.

Reports or complaints that have been audited by one institution can no longer be submitted to an examination of the other institutions. However, when there is a new report or complaint, it is possible for other institutions to re-examine the report or complaint. It can no longer be done, unless there are new complaints. If it has been examined at the Honorary Council, it will no longer be examined by the Supervisory Panel.

The imbalance of authority between the Honorary Council and the Notary Supervisory Council, especially in respect of or disrespectfully dismissed from his position as a notary, appears as a discourse discussed internally in INI. According to Adrian, the Honorary Council should also be able to propose or provide recommendations to the Notary Supervisory Council regarding ethical violations that result in the notary being dismissed. 
The reason is because the Honorary Council is only limited to dismissing notaries as members of professional organizations, in this case members of INI. There are times when a serious ethical violation committed by a notary is seen as an act that diminishes the dignity of the profession even though the violation does not constitute a violation of the law. Sometimes ethical violations are also serious violations that should no longer be worthy of him as a notary even though it is not a violation of office. This should be taken into account by the Supervisory Panel. Although the Notary Supervisory Board itself is actually authorized to examine ethical violations. However, in order to assist the work of the Notary Supervisory Council, the Honorary Council in the future should be able to forward recommendations on the dismissal of notaries from their positions to the Supervisory Council. In order to assist the Notary Supervisory Council, there should have been an Honorary Council decision which could be submitted through the Notary Supervisory Council without examination and dismissal. Although the Notary Supervisory Board itself is actually authorized to examine ethical violations. However, in order to assist the work of the Notary Supervisory Council, the Honorary Council in the future should be able to forward recommendations on the dismissal of notaries from their positions to the Supervisory Council. In order to assist the Notary Supervisory Council, there should have been an Honorary Council decision which could be submitted through the Notary Supervisory Council without examination and dismissal. Although the Notary Supervisory Board itself is actually authorized to examine ethical violations. However, in order to assist the work of the Notary Supervisory Council, the Honorary Council in the future should be able to forward recommendations on the dismissal of notaries from their positions to the Supervisory Council. In order to assist the Notary Supervisory Council, there should have been an Honorary Council decision which could be submitted through the Notary Supervisory Council without examination and dismissal.

(2) There is an unsynchronized arrangement of the authority of the Notary Honorary Council (MKN) and the Notary Supervisory Council (MPN).

Tracing the linkages between articles in the same statutory regulation and/or between other laws and regulations, it is known that the arrangements for the Notary Supervisory Council (MPN) and the Notary Honorary Council (MKN) are inconsistent between Article 1 Number 6 and Article 66A and 67. UUJN. Article 1 Number 6 UUJN regulates that MPN has the authority and obligation to carry out guidance and supervision of Notaries. Meanwhile Article 66A regulates that MKN has the authority to guide Notaries, and Article 67 provides that MPN has the authority to supervise Notaries.

Articles $66 \mathrm{~A}$ and 67 as a result of the amendment of the UUJN have clearly differentiated the powers between the MPN and the MKN. However, Article 1 Number 6, both before the amendment and after the amendment, gives legal uncertainty to the authority of notary guidance, due to the overlap of the coaching authority between MPN and MKN.

(3) There is an overlapping arrangement of the authority of the Notary Honorary Council (MKN) and the Notary Supervisory Council (MPN) as regulated by Permenkumham No.7 of 2016 (in particular Article 1 Number 1) and Article 1 Number 6 UUJN, that MKN is authorized in terms of guidance, as well as MPN. . The existence of disharmony in regulations, legal vacuum and overlapping of these arrangements causes basically legal uncertainty regarding the authority of notary development, who is the real implementer (MKN or MPN)? If both of them, how do you regulate the limits of your authority? This is not stated in the relevant laws and regulations, either UUJN or 
Permenkumham No.7 of 2016.

(4) There is a contradiction in exercising the authority of the Notary Honorary Council (MKN) and the Notary Supervisory Council (MPN)

The implementation of the powers of the MPD and MKN has experienced a number of conflicts, this is as shown by the submission of a judicial review to the Constitutional Court on Article 66 UUJN (before the amendment) as stated in the Decision of the Constitutional Court No. 49/PUU-X/2012 and Article 66 (1), (3), (4) UUJN (after amendments) as the Constitutional Court Decision No. 72/PUU-XII/2014.

In the Constitutional Court Decision No. 49/PUU-X/2012 it is known that the Petitioner (self-employed) has questioned the provisions of Article 66 of the UUJN (prior to amendment) which are deemed contrary to Article 27 Paragraph (1) and 28 D of the 1945 Constitution, that the phrase "with the approval of the MPD" is contrary to the right citizens regarding equal position before the law and government and the right of everyone to recognition, guarantee, protection and legal certainty that is just and equal treatment before the law. In this matter, the Constitutional Court is of the opinion that the requirement for MPD approval is contrary to the principle of independence in the judicial process and is contrary to the obligations of a notary as a citizen who has the same position before the law and is against the principle of equal protection.[4]This resulted in the MPD's authority to give its approval regarding Article 66 of the UUJN (before the amendment) had disappeared (no longer existed), the MPD was no longer authorized to give approval as stated in Article 66 of the UUJN (prior to amendment). This creates a legal vacuum;

In the Constitutional Court Decision No. 72/PUU-XII/2014 it is known that the Petitioner (advocate) has questioned the provisions of Article 66 (1), (3), (4) UUJN (after amendments) regarding the authority of MKN which is similar to the MPD as referred to in Article 66 UUJN (before amendment) has been declared non-binding by the Decision of the Constitutional Court No. 49/PUU-X/2012, namely regarding "the requirement for approval from the Notary Honorary Council for Notaries who will be examined in the legal process". According to the applicant, the provisions of Article 66 Paragraph (1), (3) and (4) UUJN (after the amendment) contradicts Article 27 Paragraph (1) and Article 28D Paragraph (1) and (3) of the 1945 Constitution. whereas the applicant does not have legal standing because in fact the applicant has not been harmed, as a result the principal of the petition is not considered,[5]As a result, the provisions of Article 66 Paragraph (1), (3) and (4) UUJN (after the amendment) are still valid and binding, that MKN has the authority to give the approval as intended.

Based on the two decisions of the Constitutional Court, it can be concluded that both the powers of the MPD (before the amendment of UUJN) and the authority of the MKN (after the amendment of the UUJN) have been questioned by a number of parties and wanted by the petitioner to be abolished, but in the end this authority was still valid and implemented by MKN. However, it needs to be criticized that by using the logic of thinking of the Panel of Judges in the Constitutional Court Decision No. 49/PUU-X/2012, if the applicant has legal standing, the authority of the MKN may be declared contrary to the 1945 Constitution and become non-binding as the fate of the MPD in the Constitutional Court Decision No. 49/PUU-X/2012. Notaries, especially MKN, need to pay attention to this, and fight for this authority so that this authority is not 'lost' anymore. 
(5) There is a conflict of interest between the Notary Honorary Council (MKN) and the Notary Supervisory Council (MPN)

The MKN and the MPD have historically had the same authority, namely in relation to the "granting of approval" as previously explained. First, it has been stated that the MPD is no longer authorized to give such approval, based on the Decision of the Constitutional Court No. 49/PUU-X/2012; second, then the amendment of UUJN (2014) gave this authority to the 'new institution', namely the MKN; and third, the validity of this authority is based on the Decision of the Constitutional Court No. 72/PUU-XII/2014, so clearly there is no overlapping authority between MKN and MPD. That is the description at first glance, however, if you refer to the regulations that have just been issued, namely Permenkumham No.7 of 2016 and further examining the UUJN, there are some irregularities including: (1) Permenkumham Number 7 of 2016 regulates Guidance carried out by MKN for Notaries. In this regard, by referring to Article 70 of the UUJN, the powers that be in the MPD are actually covered in the guidance of Notaries. MPD can conduct an examination, summon a Notary, in the event that the Notary violates the notary's Code of Ethics. As a result, there may be overlapping powers in terms of coaching by the two institutions; (2) Article 70 letter b UUJN and Article 66 paragraph 1 letter b UUJN regulate regarding "examination", both MKN and MPD can conduct examination to a Notary in the framework of deeds drawn up or prokol that are kept by the Notary. MPD can conduct an examination, summon a Notary, in the event the Notary violates the notary's Code of Ethics. As a result, there may be overlapping powers in terms of coaching by the two institutions; (2) Article 70 letter b UUJN and Article 66 paragraph 1 letter b UUJN regulate about "examination", both MKN and MPD can conduct examination to a Notary in the framework of deeds drawn up or prokol kept by the Notary. MPD can conduct an examination, summon a Notary, in the event the Notary violates the notary's Code of Ethics. As a result, there may be overlapping powers in terms of coaching by the two institutions; (2) Article 70 letter b UUJN and Article 66 paragraph 1 letter b UUJN regulate about "examination", both MKN and MPD can conduct examination to a Notary in the framework of deeds drawn up or prokol kept by the Notary.

The existence of the audit authority of the two institutions can create a conflict of interest if the two institutions do not clearly explain the extent of the audit authority. There must be a synchronization between the authority of the Notary Supervisory Council and the Notary Honorary Council which can be found in Act No. 30 of 2004 conceming the Position of Notary Public, Constitutional Court Decision Number 49/PUU-X/2012, Act No.2 of 2014 concerning Amendments to Act No. 30 of 2004 concerning the Position of Notary, and Regulation of the Minister of Law and Human Rights No.7 of 2016 concerning the Notary Honorary Council. Based on this regulation, it can be concluded that it is regulated that the Notary Supervisory Council (MPN) has the authority in the field of supervision, while the Notary Honorary Council (MKN) has the authority in the field of guidance. The synchronization must constitute firmness and clarity between the supervision of the Notary Supervisory Council (MPN) which has the role of supervising Notaries in terms of enforcing the Code of Ethics, implementing the position of Notary Public, and the behavior of Notaries outside their positions, with the guidance of the Notary Advisory Council (MKN) to have the authority to implement A more internal Notary Code of Ethics. 


\section{CLOSING}

Synchronization of Notary Supervision by the Notary Supervisory Council and guidance by the Notary Honorary Council in law enforcement is very necessary, especially in relation to: imbalance of authority between the Notary Supervisory Council and the Notary Honorary Council, the inconsistency in setting the authority of the Notary Honorary Council (MKN) and the Notary Supervisory Council (MPN), conflict of exercising the authority of the Notary Honorary Council (MKN) and the Notary Supervisory Council (MPN) and conflict of interest between the Notary Honorary Council (MKN) and the Notary Supervisory Council (MPN).

\section{REFERENCES}

Journal:

NI Puspita. (2019). Persetujuan Majelis Kehormatan Notaris Untuk Pengambilan Fotokopi Minuta Akta Dan Pemanggilan Notaris Dalam Rangka Proses Peradilan. Repertorium: Jurnal Ilmiah Hukum Kenotariatan 4, p.2

S Bahri, A Yahanan, A Trisaka. (2009). Kewenangan Notaris Dalam Mensertifikasi Transaksi Elektronik dalam rangka Cyber Notary, Repertorium: Jurnal Ilmiah Hukum Kenotariatan, p. 142-157

Books:

Barda Nawawi Arief. (2002). Kepentingan dalam Kebijakan Hukum Pidana. Bandung: PT Citra Aditya Bakti

Harun M. Husen. (1990). Penegakan Hukum di Indonesia. Rineka Cipta, Jakarta Ngadino. (2019). Duties and Responsibilities, Position of Notary in Indonesia. PGRI University, Semarang Press

Soerjono Soekanto, (183). Faktor Keefektifan Penegakan Hukum. UI Pres, Jakarta Soeryono Soekanto. (1986). Pengantar IImu Hukum. UI Press, Jakarta

Suhartono. (2011). Harmonization of Legislative Regulations in the Implementation of the State Budget (Efficient, Effective and Accountable Solution for State Budget Absorption), Thesis, Jakarta: University of Indonesia

Sujamto. (1987). Aspek-aspek Pengawasan di Indonesia. Jakarta: Sinar Grakika 